\title{
EXPLORING THE PRACTICES OF PEACE EDUCATION IN TEACHER TRAINING PROGRAMS AT HIGHER EDUCATION IN PAKISTAN
}

\author{
Sufi Amin \\ PhD Scholar, Department of Education, \\ International Islamic University, \\ Islamabad, Pakistan \\ Email: sufiamin777@yahoo.com

\section{Muhammad Kamran} \\ Assistant Professor, Department of Education, \\ University of Loralai, \\ Balochistan, Pakistan \\ Email: kamrankundi86@gmail.com

\section{Atif Altaf} \\ Lecturer, Department of Education, \\ University of Azad Jammu \& Kashmir, Jehlum Valley Campus, \\ AJ\&K, Pakistan \\ Email: atifaltafawan@gamil.com
}

\begin{abstract}
This study was designed for introducing peace education in pre-service teachers training programs in Khyber Pakhtunkhwa, Pakistan. Peace education is more effective and significant, when implemented according to the social and cultural perspective and the requirements of a country. It should develop the cultural and spiritual principles together with the world-wide human principles. The objectives of the present study were to find out the current practices of peace education and to determine the need of peace education in pre-service teacher training programs. Quantitative approach was used in this study. The research design of this study was survey and descriptive. Descriptive and survey research design is a technique in which huge data of quantitative and qualitative nature both were collected and analysed. The population of the study was comprised of all teacher educators and prospective teachers of Institute of educational research and department of education in all public sector universities in KP. And sample of the study consisted of 278 teacher educators and prospective teachers of Institute of educational research and department of education in all public sector universities in KP. For this research study for data
\end{abstract}


collection self-structured questionnaire was used. The research tools cover all the aspects of peace education with relevant for pre-service teachers education. Research tool was properly validated from the experts of Peace education. First questionnaire was consisted 35 items after validation it decreases to 20 statements. All the statements related to peace education in pre-service teacher training programs. While the reliability of the questionnaire was insured through test retest method. Research personally visited all the selected institutes and collected the data. Hence, it was quantitative study by nature. So, data was analysed through SPSS (Version, 20). Both descriptive and inferential statistic for example percentage and frequencies was used in the interpretation of the data. The data were presented.

\section{KEYWORDS}

Analysis, Peace, Peace Education Practices, Teacher Training Programs, SPSS

\section{INTRODUCTION}

Peace education promotes attitude, knowledge and skills for improving and maintaining the mental silence. People in modern world face many problems and issues such as ethical, ethnic, political and social. Humanity and civilizations are at the brink of destruction due to socio-economic struggle. Hence, revival of peace in the society is the need of present time. In this regard education can play important role in promoting peace from school level to society (Charles, 2013).

People and nations throughout the world are indulge in war instead of negotiations, exploitation of resources instead of proper allocations of resources, tyranny and competition instead of respect, harmony and cooperation There is no end to wars and conflicts in the world and they justify their wars as if struggle of democracy and justice. Tedneancy towards conflicts and violence has become common and usual in the world (Galtung, 2008). Spreading of wars, conflicts and violence affects people particularly children causing the anxiety and fear in their lives through electronic and social media. (Alito \& Michel, 2009). Therefore, peace education is the only way for transforming violence into peace, for growing children's awareness, skills and peaceful insolence (Harris, 2008). Due to its importance peace education is emphasized nowadays in the world but it is not practiced commonly in UK and we can rarely find the term peace education in British schools. (Hicks, 1996). Thus, peace education can be promoted in UK schools by conduction research on practices and principles of peace education. Theoretically peace education contributes in establishing the conceptual framework to lead the development programs through peace education. Hence, it is generally implanted without the rationale of research and theoretical background (Johnston, 2007).

Peace education has great importance in teacher training programs hence 
Pakistan needs to implement peace education programs not only for meeting UNESCO guidelines but for resolving conflicts within its premises and promoting harmony in the society. There is found unrest in Pakistan specifically one of its provinces Khyebr Pakhtunkhwah and a great division in the society, hence questioning the role of education and revising teacher training programs with integration of peace education is reasonable. There are a few researches conducted on teacher training programs for peace education for pre-services teacher training programs.

\section{LITERATURE REVIEW}

The Center for Peace Education (2019) says in the path of a culture of peace that peace is the absence of violence from the individual to the non-personal level and the presence of social justice. Thus it is a process of distribution of resources and wealth on the basis of high justice. According to the United Nations Educational, Scientific and Cultural Organization (UNESCO) (2015) Peace education is the knowledge that enables students to understand local and global issues, to take a positive approach to problems, a process that develops skills, attitudes, behaviors, and values, conflict resolution, nonviolent justice, living by universal standards of human rights, respecting cultural diversity, and respecting one another. Harris (2008) there are two types of peace. The first is the absence of direct peace, such as physical, verbal and psychological, between individuals, groups and governments, a negative peace that means the absence of war, violence and conflict, and the second - Positive peace, which means the existence of social justice. And equality, equitable distribution of power and resources, equal protection of the law, and impartial enforcement.

United Nations and other organizations are officially made for promoting peace education in the world. Promoting peace everywhere in the world is the main purpose of the peace education and different organizations are working in this regard to develop and stimulate peace in all parts of the world. Among these organizations the most popular are UNESCO, UNCEF, HAP, CCTP, and GCPE. The famous philosophers and theorists who define and illustrate peace education are Boulding (1988), Harris (2003) and Reardon (2001), Dane, (2012). These philosophers and theorists deliberately developed the different models of peace education according the particular conditions and situations of countries. End of $20^{\text {th }}$ century observed the demand of peace studies. For example peace education and movement began in all over the world and educationists and campaigners educated people about the violence. Educators and teacher significantly played their role in promoting peace education at school and university level. They put their efforts for developing awareness in students about the accomplishment of peace in conflicted and miscellaneous situations. There are deliberate units and subjects connecting peace education for example approaches 
meanings, kinds and goals of peace education (Harris, 2008). It is the method to promote the consciousness for discovering the ideas of peace, investigating the problems and hindrances of peace in peoples' and individual's life, resolving conflicts peacefully and researching for alternate and maintainable prospects. Peace education is the procedure and an attitude that connects abilities and emphasizes authorizing persons with understanding, outlooks and talents.

Paffenholz (2005) said that peace-building is one of the important dimensions of peace education which is used for the dispute settlement, reduce or mitigate it in all forms. The main aim of peace-building is to eradicate the root causes of conflicts and develop a social, cultural and institutional environment to promote a stable peace. Peacebuilding focuses on the development of capacities at national levels to resolve the conflicts peacefully. The peace-building process focuses on the economic, social and psychological environment and approaching peoples for justice, equality and cooperation development in the society. There are also three dimensions of peacebuilding such as structural dimensions, relational dimensions, and personal dimensions. The structural dimensions are related to social, economic, political and cultural conditions that promote burning conflicts. The relational dimension refers to the decrease in the opposing outcomes of conflicts and the development of a smooth relationship for compromises using effective dialogues between communities

It is a procedure that instills abilities, outlooks and awareness in authorizing persons and individuals for making a peaceful world in everywhere for establishing a sustainable scenario in the world. These ideas illustrate and invite adoration, pacifism, sympathy and admiration in the life of nations (Harris, 2008). Sinlarat describes two types of peace education. The first type is "education about peace" that elaborates peace education comprehensively. In this type he has discussed in detail the variety, technique, problems as well as contents of peace. The $2^{\text {nd }}$ category is "education for peace". In this type he has emphasized on contents and problem solving through peace education. He further describes that education is an instrument and process that brings quietness in persons' lives in everywhere in the world.

The UN realizing the importance of peace education is taking measures for encouraging and promoting peace education throughout the world in all of countries. Due to deficiency of peace education of member nations of United Nations has not gone successful in spreading and promoting peace education in its member countries. (Reardon, 2001). In 21th century education is the only way for capability to alter the fierceness based views in all over the globe, it does not only identify the basis of violence but propose actions and plans positively to counter those (Hayne, Auster \& Dower, 2009). Peace education is the need of the world, hence it is necessary for every country because it is establishes the principles of peace. (Cower, 2007). Huntly (2013) 
describes that different school systems will have to apply and propagate peace education in schools. According to Srinivasan (2010) \& Wiggins (2011) peace education requires educated resources persons as teachers, supporting classroom situations, syllabus improvement, community and societal provision and effective administration. The teachers have been considered the key indicators and agents for positive change and development in schools (Reardon, 2008), Teachings in the zone of peace education for teachers can help them for outlining and implementing the subject in schools and educational institutions of Pakistan.

Integration of peace education all pre-service and in-service teacher training programs and in curricula of prospective teachers is the dire need in Pakistan. Integration of peace education in teacher training programs will initiate the culture of peace on consistent basis from the institutions, schools and to the whole society ultimately Ssenkumba (2010).

Bestow (2012) Emphasizes that it is highly significant method that will bring a desired growth and change in pre-service teachers. Teachers need certain capabilities and skills for enabling them to spread peace education in schools and students and other institutions of teacher's trainings. In research it is a debate that peace education programs allow teachers to develop concentrate knowledge base of the principles and themes of peace education that is obligatory for quality information. (Reardon, 2008; Ssenkumba, 2010). Barrett (2010) also presents comparable opinions in addition to agree that peace is compulsory and important to increasing well informed, well skilled and competent teachers. Hence it is highly required to develop the capabilities and pedagogic methods of teachers through their orientation to peace education training programs (Fitzduff \& Jean (2012). Examples from Sri Lanka and Carrizo (2010) establishes that well provision of systematic training as to every teacher and school staff is significant for effective peace education programs (Reardon, 2008). It has been determined that when educators are inculcated the values and principles of peace education through comprehensive peace education programs it alter their personality, attitude, insights and world around them. It is suggested that teachers training is critical and important for societal change. Bestow (2012) Suggests that educators and teachers are the vital players and agents as the peace keepers, replicas and envois. It has shown in research that for becoming more cooperative and having extraordinary abilities of pedagogy teacher's need extraordinary training programs for presenting peace education in educational institutions (Bell, 2012).

For the empowerment of teachers in area of peace education training is very important if the teacher is empower he/she delivers each and everything's to their students, through this way teachers develops the skills of their student in this regards, and such students become peace promoters in all over the world (John, 2013). In this regard, 
different researchers work in area of peace, to make a mechanism for teachers to promote peace in classroom (Aural, 2005), in different universities and higher education institutions also started different programs in the field of peace education. To train the prospective teachers in this regards, some researcher explain the importance of peace education in the field of teacher education (Tidwell, 2004).

Higher education commission of Sri Lanka established a separate peace education institute for their prospective teachers, in this institute they were trained their prospective teachers. The main goals of this institute is that to develop the peace building skills among prospective teachers. In all over the world different nations also working in peace education in pre-serves teachers training programs. For example India, Croatia, Canada and so many other countries working in this regard (Kiggins, 2001).

Ajrami (2013) explained that peace education improves the knowledge, skills and attitudes needed to build peace. Peace education develops values and skills that help build peace. These include international education, multicultural education and environmental education. For example, multicultural education develops relationships and knowledge that are necessary for good and positive relationships between people from different cultures. Algerians (2003) argued that peace-making is an important aspect of peace education and that conflict resolution can be used to reduce or alleviate them in some way. The main goal of peace restoration is to eliminate the causes of death and develop an institutional society, culture and environment that support peace. Peacebuilding is aimed at developing the ability to resolve conflicts at the national level peacefully. The peace process focuses on the economic, social and psychological environment, justice, equality and the development of society. There are three aspects to restoring peace: the size of the structure, the appropriate dimensions, and the individual dimensions. Structural aspects depend on social, economic, political and cultural conditions. The size of the relationship means the reduction of conflicting results in conflicts and the development of positive and reconciling relationships through effective communication between communities.

Peace is a vital component for human development and development is impossible without peace. Peace is an important component that works to reduce the likelihood of conflicts between individuals, families, communities, nations, regions, and internationally (Buchanan, 2015). Peace education addresses the issues of conflict and violence and instills human rights values. Living in peace is the dream of every person, family, community and nation. Man is a social animal and seeks peace according to his best approach. Peace in society is essential for social, economic and genealogical survival. 
Wars, conflicts, exploitation and oppression can be seen all over the world. The need for time is not war, but dialogue, the fair distribution of wealth, respect, equality and cooperation to the people. Wars and conflicts are not right, but they prove in the name of democracy or justice, and thus a culture of violence can flourish. This form of culture affects the children in the community and creates anxiety and fear in their minds. It is therefore important to create a conducive environment for peace and it is impossible to find peace in any society without educating both teachers and children (Galtung, 2002). A culture of education for peace is very important in transforming violence from peace to peace. Through peace education, teachers can develop a culture of peace in the minds of children by developing peaceful attitudes and skills. Education is the only source for the development of peaceful movements (Morrison, 2003). According to the United Nations Children's Fund (ICEUNISEF), peace education has the knowledge, skills, attitudes, values and values to enable children, young people and adults to change behaviors to prevent conflict and violence and to ensure a conducive environment of peace.

According to the United Nations, the United Nations Educational, Scientific and Cultural Organization (UNESCO) is a peace that develops knowledge, skills, attitudes, behaviors and values that enable students to understand local and global issues and take a positive approach to trouble. Process to resolve conflicts, achieve nonviolent justice, live in accordance with universal norms of human rights, respect cultural diversity and respect each other. Johnson and Johnson (2006) emphasized that peace education is a process of learning information, attitudes, values and behavioral skills to resolve nonviolent conflict and develop useful and appropriate relationships. Peace education is an attempt to respond to conflict and violence on a global, national, local and personal level. Freire (2006) describes the system of transition from a culture of violence to a culture of peace through deliberate efforts in peace education. As Reardon (1988) points out, peace education is a combination of educational policy, practice, pedagogy and planning that regulates the acquisition of knowledge to ensure peace in any situation and place.

The theoretical basis of this study consisted of three theories: the theory of ethnic conflicts, the theory of the enemy system, and the theory of integrated peace. These three concepts shed light on the phenomenon studied in the analysis of the situation in Nigeria. The theory of ethnic conflicts consists of several directions. The specific direction I have taken and implemented in this research is the theory of human needs. Burton $(1979,1997)$ advanced the theory of conflict, which not only explains the dynamics of conflict, but also serves as a tool for conflict resolution and management. The theory of human needs put forward by Burton $(1979,1997)$ emphasizes that internal conflict or struggle between ethnic groups not only negates their biological 
needs, but also reveals the psychological needs associated with their growth and development. And brings immediate communities.

On the other hand, the theory of the enemy system as a theory of behavior combines elements of the theory of international relations and the psychology of development. The hostile approach to the system provides a link to classical theory by a combination of different methods. The modern nature of the hostile systemic approach makes it easier to understand and explain seemingly insurmountable problems such as terrorism and ethnic conflicts. The basic assumption of the theory of the enemy system is that people are prone to discrimination according to their nature, which accelerates the creation of enemies and allies. This event takes place at the level of individuals and groups. Dhanesh (2006) also presents the Unified Theory of Peace, which I adopted as the theoretical basis for this study. The unique theory put forward by Danesh (2006) takes a broad or holistic view of peace. Like all other human beings in nature, Danesh (2006) maintained that peace. The results of the three basic conclusions are cognitive (knowledge), emotional (love) and convective (selective) abilities. Finally, they affect the nature of man's view of the world. The unique theory of peace develops an interface between all aspects of human life, be it peace, mental, spiritual, ethical or sociopolitical ideals. (Danesh, 2006). The basis of a unified theory of peace consists of three basic concepts: unity, worldview, and human and collective development. The unique theory of peace, proposed by Danesh (2006), recognizes unity as the basic law that underlies all human relations with conflict, which implies a lack of unity.

\section{Conceptual Framework \\ Peace}

Long stories showed peace when there was no war or violence. However, a clear definition of peace is a problem or debate. What is common sense, but peace is twosided. True peace is about a situation where people and groups can live in a way that allows their candidates to thrive well to meet their needs and aspirations. In a peaceful environment, social enterprises cannot contribute to economic, poverty, and police coercion. Peace, on the other hand, is not related to the absence of war or directly related to violence, such as physical injury. Violence is not a good thing.

\section{Peace education}

Many authors have created a definition of peace education. However, I did apply the definition given by Fountain (1999, p. 6). Education sources of water are defined as the process to enhance the knowledge, skill, attitudes, and values that are required to carry change behavior that can reach children, youth, and adults to prevent conflict and violence. These changes can be open and structural, to resolve conflicts peacefully and create conditions conducive to any peace at the interpersonal, interpersonal, intergroup, national or international levels. 


\section{Peace building}

The concept of restoring peace and managing peace in conflict is a reliable means of preventing armed conflict or recurrence, persistence and other emergencies in the development of political, humanitarian and human rights (Okoro, 2012, Karame, 2004). Thus, the above definition implies that the peace process includes pre-conflict and post-conflict stages. The main goal of restoring peace is to create a stable foundation for peace in a conflicted society. The main focus in peacebuilding is on the economic, social, and psychological worlds of ordinary people (Karame, 2004). United Theory of Peace encompasses all aspects of human life, whether in a psychological, mental, moral, or socio-political paradigm (Danesh, 2006). This view is consistent with Harris's (2004) conclusion that peace education is composed of complementary and complementary aspects. These factors ultimately include, but are not limited to, human rights education, development education, and conflict resolution education. Most importantly, for peace education to be effective, it must be the foundation of a lifestyle. This approach is consistent with the concept of peace education, as noted by Cardozo (2008). This is especially true of deliberate policies and efforts to incorporate the principles of peace education into school curricula, leading to a shift in people's learning to live together. It also promotes tolerance for one another and respects the worldview of unity by acknowledging the differences between them.

The approach of this study is to quantitative explore the potential of peace education to address the problem of insurgency, violence and terrorism. This method is suggested by Danesh (2006), with a methodology of peace education and a unified theory, with an emphasis on unity. Peace and unity are needed for Nigeria to participate in the peace it needs. Thus, the application of peace education in school curricula from the primary, secondary and university levels is part of a research approach. This movement helps citizens to develop the ideals of peace at an early stage in order to become a way of life. The inevitable consequence is that citizens do not see violence as a quick and vital option to resolve future differences.

\section{RESEARCH OBJECTIVES}

1. To find out the current practices of peace education in pre-service teacher training programs in Khyber Pakhtunkhwa, Pakistan.

2. To determine the opinions of teacher educators and Prospective teachers about the need of peace education in pre-service teacher training programs in Khyber Pakhtunkhwa, Pakistan.

\section{RESEARCH QUESTIONS}

1. What are the current practices of peace education in pre-service teacher training programs in Khyber Pakhtunkhwa, Pakistan?

2. What are the opinions of teacher educators and Prospective teachers about the need 
of peace education in pre-service teacher training programs in Khyber Pakhtunkhwa, Pakistan?

\section{RESEARCH METHODOLOGY}

Quantitative approach was used in this study. The research design of this study was survey and descriptive. Descriptive and survey research design is a technique in which huge data of quantitative and qualitative nature both were collected and analysed. The population of the study was comprised of all teacher educators and prospective teachers of Institute of educational research and department of education in all public sector universities in Khyber Pakhtunkhwa Pakistan. Sample of the study consisted of 278 teacher educators and prospective teachers of Institute of educational research and department of education in all public sector universities in Khyber Pakhtunkhwa Pakistan. For this research study for data collection self-structured questionnaire was used. The research tools cover all the aspects of peace education with relevant for preservice teachers education. Research tool was properly validated from the experts of Peace education. First questionnaire was consisted 35 items after validation it decreases to 20 statements. All the statements related to peace education in pre-service teacher training programs. While the reliability of the questionnaire was insured through test retest method. Research personally visited all the selected institutes and collected the data. Hence, it was quantitative study by nature. So, data was analysed through SPSS (Version, 20). Both descriptive and inferential statistic for example percentage and frequencies was used in the interpretation of the data. The data were presented in the form of tables.

\section{RESEARCH FINDINGS}

Table 1

Views of the Respondents Regarding Prevailing Practices of Peace Education in PreService Teacher Training Programs

\begin{tabular}{|c|c|c|c|c|c|c|c|}
\hline $\mathbf{S} \# \mathbf{N}$ & Statements & $\begin{array}{c}\text { SA } \\
\mathbf{f} \\
(\%)\end{array}$ & $\begin{array}{c}\mathbf{A} \\
\mathbf{f} \\
(\%) \\
\end{array}$ & $\begin{array}{c}\text { UNC } \\
\mathbf{f} \\
(\%)\end{array}$ & $\begin{array}{c}\text { DA } \\
\text { f } \\
(\%) \\
\end{array}$ & $\begin{array}{c}\text { SDA } \\
\mathbf{f} \\
(\%) \\
\end{array}$ & $\begin{array}{c}\mathbf{N} \\
\mathbf{f} \\
(\%) \\
\end{array}$ \\
\hline 1 & $\begin{array}{l}\text { Conflict } \\
\text { Resolution } \\
\text { Strategies }\end{array}$ & $\begin{array}{c}55 \\
(34.6)\end{array}$ & $\begin{array}{c}69 \\
(43.4)\end{array}$ & $\begin{array}{c}15 \\
(9.4)\end{array}$ & $\begin{array}{c}14 \\
(8.8)\end{array}$ & $\begin{array}{c}06 \\
(3.8)\end{array}$ & $\begin{array}{c}159 \\
(100.0)\end{array}$ \\
\hline 2 & $\begin{array}{l}\text { Global } \\
\text { Awareness }\end{array}$ & $\begin{array}{c}58 \\
(36.5)\end{array}$ & $\begin{array}{c}77 \\
(48.4)\end{array}$ & $\begin{array}{c}7 \\
(4.4)\end{array}$ & $\begin{array}{c}17 \\
(10.7)\end{array}$ & $\begin{array}{c}00 \\
(00.0)\end{array}$ & $\begin{array}{c}159 \\
(100.0)\end{array}$ \\
\hline 3 & $\begin{array}{l}\text { Promotes } \\
\text { Peace }\end{array}$ & $\begin{array}{c}33 \\
(20.8)\end{array}$ & $\begin{array}{c}60 \\
(37.7)\end{array}$ & $\begin{array}{c}47 \\
(29.6)\end{array}$ & $\begin{array}{l}15 \\
(9.4)\end{array}$ & $\begin{array}{c}04 \\
(2.5)\end{array}$ & $\begin{array}{c}159 \\
(100.0)\end{array}$ \\
\hline 4 & $\begin{array}{l}\text { Justice \& } \\
\text { Compassion }\end{array}$ & $\begin{array}{c}34 \\
(21.4)\end{array}$ & $\begin{array}{c}69 \\
(43.4)\end{array}$ & $\begin{array}{c}25 \\
(15.7)\end{array}$ & $\begin{array}{c}27 \\
(17.0)\end{array}$ & $\begin{array}{c}04 \\
(2.5)\end{array}$ & $\begin{array}{c}159 \\
(100.0)\end{array}$ \\
\hline
\end{tabular}


PJER, Vol 3, Issue 2 (2020)

Exploring the practices...

\begin{tabular}{clcccccc}
\hline 5 & Peace in the & 16 & 63 & 45 & 28 & 07 & 159 \\
& Society & $(10.1)$ & $(39.6)$ & $(28.3)$ & $(17.6)$ & $(4.4)$ & $(100.0)$ \\
6 & Human & 42 & 49 & 46 & 23 & 05 & 159 \\
& Dignity & $(26.4)$ & $(30.8)$ & $(25.2)$ & $(14.5)$ & $(3.1)$ & $(100.0)$ \\
7 & Human & 33 & 68 & 20 & 31 & 07 & 159 \\
& Relations & $(20.8)$ & $(42.8)$ & $(12.6)$ & $(19.5)$ & $(4.4)$ & $(100.0)$ \\
8 & Positive & 31 & 52 & 50 & 26 & 00 & 159 \\
& Attitudes & $(19.5)$ & $(32.7)$ & $(31.4)$ & $(16.4)$ & $(00.0)$ & $(100.0)$ \\
9 & Self-respect & 33 & 51 & 45 & 22 & 08 & 159 \\
& Overcomes & $(20.8)$ & $(32.1)$ & $(28.3)$ & $(13.8)$ & $(5.0)$ & $(100.0)$ \\
10 & Violence & $(32.7)$ & $(33$ & 35 & 14 & 05 & 159 \\
& Van & & $(22.0)$ & $(8.8)$ & $(3.1)$ & $(100.0)$ \\
\hline
\end{tabular}

Table 1 presents that $78 \%$ agreed, $13 \%$ disagreed and $9 \%$ undecided regarding conflict resolution strategies. $76 \%$ agreed, $11 \%$ disagreed and $4 \%$ undecided about global awareness. $58 \%$ agreed, $12 \%$ disagreed and $30 \%$ undecided regarding promotes peace. $65 \%$ agreed, $20 \%$ disagreed and $15 \%$ undecided regarding justice and compassion. $50 \%$ agreed, $22 \%$ disagreed and $28 \%$ undecided regarding peace in the society. $57 \%$ agreed, $25 \%$ disagreed and $17 \%$ undecided regarding human dignity. $63 \%$ agreed, $24 \%$ disagreed and $13 \%$ undecided regarding human relations. 54\% agreed, $16 \%$ disagreed and $32 \%$ undecided regarding positive attitudes. 53\% agreed, $14 \%$ disagreed and $28 \%$ undecided regarding self-respect and 66\% agreed, $12 \%$ disagreed and $22 \%$ undecided regarding overcomes violence.

Table 2

Views of Teacher Educators and Prospective Teachers Regarding the Need of Peace Education in Pre-Service Teacher Training Programs

\begin{tabular}{|c|c|c|c|c|c|c|c|}
\hline $\mathbf{S \# N}$ & Statements & $\begin{array}{c}\text { SA } \\
\text { f } \\
(\%) \\
\end{array}$ & $\begin{array}{c}\mathbf{A} \\
\mathbf{f} \\
(\%) \\
\end{array}$ & $\begin{array}{c}\text { UNC } \\
\mathbf{f} \\
(\%)\end{array}$ & $\begin{array}{c}\text { DA } \\
\text { f } \\
(\%)\end{array}$ & $\begin{array}{c}\text { SDA } \\
\text { f } \\
(\%) \\
\end{array}$ & $\begin{array}{c}\mathbf{N} \\
\mathbf{f} \\
(\%) \\
\end{array}$ \\
\hline & Develops & 56 & 53 & 30 & 11 & 09 & 159 \\
\hline 1 & Social Justice & $(35.2)$ & (33.3) & (18.9) & (6.9) & (5.7) & (100.0) \\
\hline 2 & $\begin{array}{l}\text { Develops } \\
\text { Values }\end{array}$ & $\begin{array}{c}58 \\
(36.5)\end{array}$ & $\begin{array}{c}53 \\
(33.3)\end{array}$ & $\begin{array}{c}29 \\
(18.2)\end{array}$ & $\begin{array}{c}15 \\
(9.4)\end{array}$ & $\begin{array}{c}04 \\
(2.5)\end{array}$ & $\begin{array}{c}159 \\
(100.0)\end{array}$ \\
\hline 3 & $\begin{array}{l}\text { Teacher more } \\
\text { Responsible } \\
\text { Discriminating }\end{array}$ & $\begin{array}{c}34 \\
(21.4)\end{array}$ & $\begin{array}{c}77 \\
(48.4)\end{array}$ & $\begin{array}{c}21 \\
(13.2)\end{array}$ & $\begin{array}{c}19 \\
(11.9)\end{array}$ & $\begin{array}{c}08 \\
(5.0)\end{array}$ & $\begin{array}{c}159 \\
(100.0)\end{array}$ \\
\hline 4 & $\begin{array}{l}\text { Knowledge } \\
\text { about Human } \\
\text { Rights }\end{array}$ & $\begin{array}{c}31 \\
(19.5)\end{array}$ & $\begin{array}{c}83 \\
(52.2)\end{array}$ & $\begin{array}{c}27 \\
(17.0)\end{array}$ & $\begin{array}{c}13 \\
(8.3)\end{array}$ & $\begin{array}{c}05 \\
(3.1)\end{array}$ & $\begin{array}{c}159 \\
(100.0)\end{array}$ \\
\hline
\end{tabular}


PJER, Vol 3, Issue 2 (2020)

Exploring the practices...

\begin{tabular}{|c|c|c|c|c|c|c|c|}
\hline 5 & $\begin{array}{l}\text { Building } \\
\text { Harmony }\end{array}$ & $\begin{array}{c}31 \\
(19.5)\end{array}$ & $\begin{array}{c}68 \\
(42.8)\end{array}$ & $\begin{array}{c}37 \\
(23.3)\end{array}$ & $\begin{array}{c}11 \\
(6.9)\end{array}$ & $\begin{array}{c}12 \\
(7.5)\end{array}$ & $\begin{array}{c}159 \\
(100.0)\end{array}$ \\
\hline 6 & $\begin{array}{l}\text { Develop } \\
\text { Social Peace }\end{array}$ & $\begin{array}{c}27 \\
(17.0)\end{array}$ & $\begin{array}{c}61 \\
(38.4)\end{array}$ & $\begin{array}{c}45 \\
(28.3)\end{array}$ & $\begin{array}{c}16 \\
(10.1)\end{array}$ & $\begin{array}{c}10 \\
(6.3)\end{array}$ & $\begin{array}{c}159 \\
(100.0)\end{array}$ \\
\hline 7 & $\begin{array}{l}\text { Stimulates } \\
\text { Truth }\end{array}$ & $\begin{array}{c}42 \\
(26.4)\end{array}$ & $\begin{array}{c}46 \\
(28.9)\end{array}$ & $\begin{array}{c}35 \\
(22.0)\end{array}$ & $\begin{array}{c}21 \\
(13.2)\end{array}$ & $\begin{array}{c}15 \\
(9.4)\end{array}$ & $\begin{array}{c}159 \\
(100.0)\end{array}$ \\
\hline 8 & $\begin{array}{l}\text { Builds } \\
\text { Positive } \\
\text { Thinking }\end{array}$ & $\begin{array}{c}36 \\
(22.6)\end{array}$ & $\begin{array}{c}51 \\
(32.1)\end{array}$ & $\begin{array}{c}51 \\
(32.1)\end{array}$ & $\begin{array}{c}09 \\
(5.7)\end{array}$ & $\begin{array}{c}12 \\
(7.5)\end{array}$ & $\begin{array}{c}159 \\
(100.0)\end{array}$ \\
\hline 9 & $\begin{array}{l}\text { Develop } \\
\text { Values }\end{array}$ & $\begin{array}{c}24 \\
(15.1)\end{array}$ & $\begin{array}{c}75 \\
(47.2)\end{array}$ & $\begin{array}{c}42 \\
(26.4)\end{array}$ & $\begin{array}{c}10 \\
(6.3)\end{array}$ & $\begin{array}{c}08 \\
(5.0)\end{array}$ & $\begin{array}{c}159 \\
(100.0)\end{array}$ \\
\hline 10 & $\begin{array}{l}\text { Develop } \\
\text { Inner-peace }\end{array}$ & $\begin{array}{c}65 \\
(40.9)\end{array}$ & $\begin{array}{c}43 \\
(27.0)\end{array}$ & $\begin{array}{c}36 \\
(22.6)\end{array}$ & $\begin{array}{l}15 \\
(9.4)\end{array}$ & $\begin{array}{c}00 \\
(00.0)\end{array}$ & $\begin{array}{c}159 \\
(100.0)\end{array}$ \\
\hline
\end{tabular}

Table 2 shows that $66 \%$ agreed, $14 \%$ disagreed and $19 \%$ undecided regarding develops social justice. $69 \%$ agreed, $12 \%$ disagreed and $18 \%$ undecided regarding develops values. 58\% agreed, $12 \%$ disagreed and 30\% undecided regarding teacher more responsible. $72 \%$ agreed, $11 \%$ disagreed and $17 \%$ undecided regarding discriminating knowledge about human rights. 63\% agreed, 16\% disagreed and 28\% undecided regarding building harmony. 54\% agreed, $25 \%$ disagreed and $17 \%$ undecided regarding develop social peace. $63 \%$ agreed, $24 \%$ disagreed and $13 \%$ undecided regarding stimulates truth. 55\% agreed, 15\% disagreed and 32\% undecided regarding builds positive thinking. $62 \%$ agreed, $11 \%$ disagreed and $268 \%$ undecided regarding Develop Values and 67\% agreed, 9\% disagreed and 232\% undecided regarding develop inner-peace.

\section{CONCLUSIONS AND DISCUSSIONS}

On the basis of findings of the study majority of the teacher educators and prospective teachers agreed that peace education is a process which develops some basic and compulsory skills among teacher's educators and prospective teachers. These skills are: conflict resolution strategies, global awareness, justice and compassion, human dignity, human relations, self-respect, overcomes violence, social justice, human rights, and stimulates truth and so many skills which develops peace education among teacher educators and prospective teachers. It is also concluded that peace education is very important for 21th century. Because it is the age of destruction and scientific inventions. Every country going towards war and conflicts. Therefore, peace education through teacher training is the best solution. To overcome such war and conflicts in this universe. In view of the above findings, the following conclusions were drawn in accordance with the purpose of the study; teacher education has a positive impact on the implementation of peace education. This variable has a positive impact on any curriculum, such as the implementation of peace education innovations. The institution should establish procedures for monitoring and evaluating the curriculum and 
providing technical assistance to teachers in need. The fact that monitoring and evaluation is rarely performed is partly explained by the ease of implementation of the program. This finding contradicts the ethics of monitoring and evaluation. BaratsSnowden (2009) argues that teacher evaluation is often used to improve teaching and learning, as well as for reporting. If this is not done, the expectations for successful implementation will be much higher than the value, as found in this study. The lack of regular monitoring and evaluation calls into question the quality of teaching in the school system in this sensitive area and in the education system. Studies show that the best school systems do not allow ineffective teachers to stay in class long (Gordon, Kane \& Stanjer; 2006; Kane, Rockoff \& Stanger 2006; McKinsey, 2007).

\section{RECOMMENDATIONS}

1. Peace education practices should be incorporate in classroom discussion and teacher can easily transfer such skills into students.

2. Ministry of education should be made curriculum of peace education for pre-service teacher's education.

3. Develop a policy, to stimulate peace education in pre-service teacher training programs in Pakistan.

4. Ministry of Education should provide chance for the development of peace education in teacher training programs in Pakistan

\section{REFERENCES}

Ajrami, A. (2013). The Palestinian political discourse: The impact of different social components, discourse, culture, and education in the Israeli-Palestinian conflict. In Discourse, culture, and education in the Israeli-Palestinian conflict ( $\mathrm{pp} \mathrm{10-16).}$ Netanya, Israel: Netanya Academic College.

Alger, C. F. (2002). Religion as a peace tool. Global Review of Ethno politics, 1(4), 94-109.

Alito, E. \& Michel, J. (2009), Primary Review: Community Soundings. Cambridge: University of Cambridge, Faculty of Education.

Aural, P.F. (2005). UNESCO report on national capacity-building of Lead Teacher Training Institutions in Zimbabwe, 1-29.

Bestow, B. (2012). Teaching to transform, transforming to teach: Exploring the role of teachers in human rights education in India. Educational Research, Vol. 53, No. 2:207-221.

Bell, K., Right, G. \& Nelson, S. (2012). Peace Education in societies involved in intractable conflicts: Goals, conditions and directions. In Salomon, G. and Cairns, E. (Eds.), Handbook on Peace Education, 2143. New York: Psychology Press.

Borg, S. (2006). Teacher cognition and language education: Research and practice. London: Continuum.

Boulding, E. (1988), Building a Global Civic Culture: Education for an Interdependent World (Syracuse, N.Y: Syracuse University Press). 
Buchanan, R. (2015). Global Terrorism Index: Nigerian Fulani Militants named as fourth deadliest terror group in world, http://www.google.com, independent.co.uk $\backslash$ new $\backslash$ world \Africalglobal-terrorism-index-nigerian-fulanimilitants-96739851.html Posted Wednesday, 18, November, 2015

Boyden, J. \& Ryder, P. (1996). The provision of education to children affected by armed conflict. Oxford: Refugee Studies Centre.

Burton, J. (1979). Deviance, terrorism and war: The process of solving unsolved social and political problems. New York, NY: Palgrave Macmillan.

Burton, J (1990). Conflict resolution and prevention. New York, NY: St. Martin's Press

Burton, J (1997). Violence Experienced: The source of conflict, violence and crime and their prevention. New York, NY: Manchester University Press.

Cardozo, M. T. A. L. (2008). Sri Lanka: In peace or in pieces? A critical approach to peace education in Sri Lanka. Research in Comparative and International Education, 3(1), 19-35.

Charles, L. J. (2013), Peace Education at School Level-Needs and Means. Golden Research Thoughts Vol. 2 Issue 12.

Cower, M.H. (2007). Welcome Speech, 1-5. The conference hosted by the Hague Appeal for peace on developing democracy through peace education: Educating toward a world without violence, 20 October 2007, Linza, Albania.

Danesh, H. B. (2006). Towards an integrative theory of peace education. Journal of Peace Education, 3(1), 55-78.

Danesh, H. B. (2008). The education for peace integrative curriculum: Concepts, contents and efficacy. Journal of Peace Education, 5(2), 157-173.

Dane, L. N. (2012). Distinctive aspects of education for peace. In Danesh, H. B. (Ed.), Education for Peace Reader, 11-17. Victoria: EFP Press.

Feiman-Nemser, S. \& Floden, R. E. (2001). The cultures of teaching. In: M. C. Wittrock (Ed.), Handbook of research on teaching (pp. 505-526). New York: Macmillan.

Frits, N. \& Jan, K. (2012). Peace education: State of the field and lessons learned from USIP grant-making. Washington, D.C: Unites States Institute of Peace.

Galtung, J. (2008), 'Form and Content of Peace Education', in M. Bajaj (ed.), Encyclopedia of Peace Education (NC: Teacher College, Columbia University).

Galtung, J., \& Jacobsen, C. G. (2000). Searching for peace: The road to transcend. London, United Kingdom: Pluto Press.

Hicks, D. (1996), racial justice, Global development or Peace. 'In Burns, R.J. \& Aspeslagh, R. (eds.) Three Decades of Peace Education around the World. New York: Garland Publisher.

Huntly, S. (2013). Institutionalizing critical peace education in public schools: A case for comprehensive implementation. Journal of Peace Education, Vol.8, No.3: 225-242.

Harris, I.M. (2008). Challenges for peace educators at the beginning of the 21 st century. Social Alternatives, Vol.21, No.1: 28-33.

Hayne, K.Y, Auster, J. \& Dower, L. (2009). Integrated education, intergroup relations, and political identities in Northern Ireland. Social Problems, Vol. 54, Issue 4: 454-482.

Johnston, A. R. (2007), This Issue: Peace Education. 'Theory into Practice. Vol.44, Issue 4, pp. 275-279.

Kane, S. \& Stanjer, R. E. (2006). The cultures of teaching. In: M. C. Wittrock 
(Ed.), Handbook of research on teaching (pp. 505-526). New York: Macmillan.

Karame, K. (Ed.). (2004). Gender and peace building in Africa. Oslo, Norway: TfP and NUPI.

McKinsey, M. (2007). A Baseline survey report on school-based Peace Education and Guidance and Counseling in Secondary Schools in Northern Uganda, 1-60.

Morrison, M. L. (2003). Peace education (2nded.) Jefferson, NC: McFarland.

Okoro, K. (2012). African concept of INOCHI: A new paradigm for peace education in the contemporary society, Modern Social Science Journal, 2(2), 87-112.

Pollock, M. (2010). Professionalization of teacher education in India: A critique of teacher education curriculum reforms and its effectiveness, 1-13.

Reardon, B.A. (1988). Education for a culture of peace in a gender perspective. Paris: UNESCO Publications.

Reardon, B.A. (2001). Education for a culture of peace in a gender perspective. Paris: UNESCO Publications.

Srinivas, T. (2010). A survey of civil society peace education program in South Asia. Educational Policy Research Series, Vol. I, No 2: 1-74.

Ssenkumba, M. (2010). A Baseline survey report on school-based Peace Education and Guidance and Counseling in Secondary Schools in Northern Uganda, 1-60.

Wiggins, O.K. (2011). The search for balance: Understanding and implementing yoga, peace, and democratic education. Journal of Peace Education and Social Justice, Vol. 5, No.2: 216-234. 